\title{
RESPONSE OF STRAWBERRY 'SELVA' PLANTS ON FOLIAR APPLICATION OF SODIUM NITROPRUSSIDE (NITRIC OXIDE DONOR) UNDER SALINE CONDITIONS
}

\author{
Babak JAMALI ${ }^{1}$, Saeid ESHGHI ${ }^{1 *}$, Bahman KHOLDEBARIN ${ }^{2}$ \\ ${ }^{1}$ Department of Horticultural Science, College of Agriculture, Shiraz University, Shiraz, Iran \\ ${ }^{2}$ Department of Biology, College of Science, Shiraz University, Shiraz, Iran
}

Received: July 22, 2014; Accepted: December 10, 2014

\begin{abstract}
This study was conducted to evaluate enzymatic and non-enzymatic antioxidant response of 'Selva' strawberry plants on exogenous nitric oxide under saline conditions with respect to time of application. Sodium nitroprusside (SNP), as nitric oxide (NO) source, was applied on the leaves by spray before, simultaneously, or after the initiation of saline stress. Results indicated that salinity and/or SNP at concentrations of 50 and $75 \mu \mathrm{M}$ caused increase in activity of antioxidant enzymes, such as catalase, superoxide dismutase, glutathione reductase, ascorbate peroxidase and peroxidases as well as leaf content of proline, glycine betaine and total phenolics in comparison to control. Time of NO application was important because the highest levels of catalase and ascorbic peroxidase were in plants pre-treated with SNP one week before the initiation of salinity stress. Plants from these combinations had the highest fruit yield among all saline stressed plants. So, it seems that earlier application of SNP is more effective for an optimised protection against deleterious influence of salinity stress, because pre-treated plants had a sufficient time to develop an appropriate antioxidant response. The application of SNP simultaneously or after exposure of plants to stress conditions, was also helpful in increasing plant tolerance but to a lesser extent.
\end{abstract}

Key words: strawberry, nitric oxide, salt stress, antioxidant enzymes, proline, glycine betaine, phenolics

\section{INTRODUCTION}

Soil salinity is a serious threat to global crop production. More than $20 \%$ of agricultural land is affected by salinity worldwide due to climate change; it is expected that this will increase in the near future (Wassmann et al. 2009). Salt stress leads to stomatal closure, which reduces $\mathrm{CO}_{2}$ availability in the leaves and inhibits carbon fixation, exposing chloroplasts to excessive excitation energy, which in turn increases the generation of reactive oxygen species (ROS) such as superoxide, hydrogen peroxide $\left(\mathrm{H}_{2} \mathrm{O}_{2}\right)$, hydroxyl radical and singlet oxygen (Ahmad \& Sharma 2008). In many plant studies, it was observed that production of ROS is increased under saline conditions (Hasegawa et al. 2000). ROS are highly reactive and may cause cellular damage through oxidation of lipids, proteins and nucleic acids (Ahmad et al. 2010).

Nitric oxide (NO) has now gained significant place in plant science, mainly due to its multifunctional role as bioactive molecule in plant growth and development (Siddiqui et al. 2011). NO exerts a protective function against oxidative stress mediated by reaction with lipid radicals, which stops the lipid oxidation; scavenge the singlet oxygen and formation of peroxynitrites that can be neutralised by other cellular processes. It also helps in the activation of antioxidant enzymes such as superoxide dismutase, glutathione reductase and functions as a signalling molecule in the cascade of events leading to gene expression. These mechanisms together enhance protection against oxidative stress (Hasanuzzaman et al. 2010). The exogenous application of sodium 
nitroprusside (SNP), a NO donor, significantly alleviated the oxidative damage of salinity in seedlings of rice (Uchida et al. 2002), lupin (Kopyra $\&$ Gwozdz 2003) and cucumber (Fan et al. 2007), enhanced the seedlings growth (Song et al. 2009) and increased the dry weight of maize and Kosteletzkya virginica seedlings (Guo et al. 2009).

Production of strawberry fruits is an ever increasing industry. This plant is considered as one of the most sensitive species to saline conditions (Yilmaz \& Kina 2008). Accumulation of salts and increased level of soil salinity may lead to damages to strawberry plants and reduction of yield and quality parameters (Kepenek \& Koyuncu 2002; Keutgen $\&$ Keutgen 2003; Saied et al. 2005). Salinity stress tolerance of strawberry plants can be modified by NO. Beneficial influence of NO on improvement of growth in different plant species under saline conditions has been reported previously as it was mentioned earlier. However, in majority of these studies, the probable temporal aspect of application (prior, simultaneously or after stress initiation) of NO has not been studied. The goal of this study was to evaluate the effect of time of application of SNP, as NO donor under saline conditions, on enzymatic and non-enzymatic antioxidant responses of strawberry 'Selva' plants to assess the time when the maximum of beneficial influence of exogenous NO could be achieved.

\section{MATERIALS AND METHODS}

\section{Plant growth conditions and treatments}

Uniformly rooted daughter plants of strawberry 'Selva' were potted in $3 \mathrm{~L}$ plastic pots filled with $1: 1(\mathrm{v} / \mathrm{v})$ ratio of peat moss and perlite. After the initiation of growth in plants (after 7 weeks), when they had four or five fully expanded leaves, they were divided into 10 groups based on the treatment as mentioned below:

1. Control (C), sprayed with distilled water,

2. Plants exposed to $40 \mathrm{mM} \mathrm{NaCl}$ salinity stress and sprayed with distilled water $(\mathrm{NaCl})$,

3. Plants sprayed with $50 \mu \mathrm{M}$ SNP solution under non-stress conditions (SNP50),

4. Plants sprayed with $75 \mu \mathrm{M}$ SNP solution under non-stress conditions (SNP75),
5. Plants sprayed with $50 \mu \mathrm{M}$ SNP solution 7 days before initiation of $40 \mathrm{mM} \mathrm{NaCl}$ salinity stress $(\mathrm{SNP} 50 \rightarrow \mathrm{NaCl})$,

6. Plants sprayed with $75 \mu \mathrm{M}$ SNP solution 7 days before initiation of $40 \mathrm{mM} \mathrm{NaCl}$ salinity stress $(\mathrm{SNP} 75 \rightarrow \mathrm{NaCl})$,

7. Plants sprayed with $50 \mu \mathrm{M}$ SNP solution simultaneously with initiation of $40 \mathrm{mM} \mathrm{NaCl}$ salinity stress (SNP50-NaCl),

8. Plants sprayed with $75 \mu \mathrm{M}$ SNP solution simultaneously with initiation of $40 \mathrm{mM} \mathrm{NaCl}$ salinity stress (SNP75-NaCl),

9. Plants exposed to $40 \mathrm{mM} \mathrm{NaCl}$ salinity and after 7 days sprayed with $50 \mu \mathrm{M}$ SNP solution $(\mathrm{NaCl} \rightarrow$ SNP50),

10.Plants exposed to $40 \mathrm{mM} \mathrm{NaCl}$ salinity and after 7 days sprayed with $75 \mu \mathrm{M}$ SNP solution $(\mathrm{NaCl} \rightarrow \mathrm{SNP75}$ ).

Plants were grown under natural light (>800 $\mu \mathrm{mol} \cdot \mathrm{m}^{-2} \cdot \mathrm{S}^{-1}$ ) in the greenhouse. Average day and night temperatures were $21 \pm 2 / 17 \pm 2{ }^{\circ} \mathrm{C}$. Relative humidity was about $60 \pm 5 \%$. Until full growth, the plants were fertigated with $150 \mathrm{~mL}$ (this volume of nutrient solution was selected according to $\mathrm{RH}$, average temperature, sunlight and pots size) of $0.5 \times$ Hoagland's nutrient solution and then with $150 \mathrm{~mL}$ of $1 \times$ Hoagland's nutrient solution once a day. Surpluses of solution were allowed to pass through the containers to ensure salt stress in the root medium at a given concentration, also to avoid anoxia by water logging. SNP spray solutions in distilled water at the concentrations 50 or $75 \mu \mathrm{M}$ was used as NO donor. Fully expanded and mature leaves were used for measurements. Bulk samples were analysed (one leaf from each pot).

On the 6th day of week 1, the first round of leaf sampling was carried out, on the next day (the 7th day of experimental period), SNP treatments on the groups 3, 4, 5 and 6 were conducted. On the 6th day of week 2 , the second round of sampling was carried out, on the following day (the 14th day of experimental period), SNP treatments on the groups 7 and 8 were conducted. From the 14th day onwards salt stress was initiated in the groups 2 , and $5-10$ by adding $\mathrm{NaCl}$ to Hoagland nutrient solution to the concentration $40 \mathrm{mM}$ and continued till the end of experiment. In order to avoid precipitation, nutrient 
solution was stirred after $\mathrm{NaCl}$ addition. In the 6th day of week 3 , the third round of sampling was carried out, and on the following day (the 21st day of experimental period), SNP treatments on the groups 9 and 10 were conducted. On the 7th day of week 4, the fourth round of sampling was carried out. Control plants received only Hoagland's fertilisation and water spray.

\section{Measurements}

For enzyme extraction, leaves $(0.5 \mathrm{~g})$ were ground to fine powder in liquid nitrogen with mortar and pestle and then homogenised in $2 \mathrm{~mL}$ extraction buffer containing $10 \%(\mathrm{w} / \mathrm{v})$ polyvinylpyrrolidone (PVP) in $50 \mathrm{mM}$ potassium-phosphate buffer $(\mathrm{pH}$ 8), containing $0.1 \mathrm{mM}$ ethylenediaminetetraacetic acid (EDTA), $1 \mathrm{mM}$ dithiothreitol (DTT). The homogenate was centrifuged $(15000 \times \mathrm{g})$ at $4{ }^{\circ} \mathrm{C}$ for $30 \mathrm{~min}$. Then, the supernatants were collected.

Glutathione reductase (GR, EC 1.6.4.2) activity was determined by following the rate of glutathione oxidised or GSSG-dependent oxidation of $\mathrm{NADPH}$, through the decrease in the absorbance at $340 \mathrm{~nm}$. The assay mixture ( $1 \mathrm{~mL}$ final volume) was composed of $0.4 \mathrm{M}$ potassium phosphate buffer (pH 7.5), $0.4 \mathrm{mM} \mathrm{Na} 2$ EDTA, $5.0 \mathrm{mM} \mathrm{GSSG}$ and $100 \mu \mathrm{L}$ of crude extract. The reaction was initiated by the addition of $2.0 \mathrm{mM}$ NADPH. Corrections were made for the background absorbance at $340 \mathrm{~nm}$ without NADPH. Activity was expressed as units ( $\mu$ mol of NADPH oxidised per minute) per milligram of protein (Foyer \& Halliwell 1976).

Superoxide dismutase (SOD, EC 1.11.1.5) activity was assayed according to Dhindsa et al. (1980). One millilitre of the reaction mixture contained $13 \mathrm{mM}$ methionine, $25 \mathrm{mM}$ nitro-blue tetrazolium chloride (NBT), $0.1 \mathrm{mM}$ EDTA, $50 \mathrm{mM}$ phosphate buffer ( $\mathrm{pH} 7.8$ ), $50 \mathrm{mM}$ sodium carbonate and $0.1 \mathrm{~mL}$ enzyme. Reaction was started by adding $2 \mathrm{mM}$ riboflavin and placing the tubes under two $15 \mathrm{~W}$ fluorescent lamps for $15 \mathrm{~min}$. A complete reaction mixture without enzyme, which gave the maximal colour, served as control. Reaction was stopped by switching off the lights and keeping the tubes in dark. A non-irradiated complete reaction mixture served as a blank. The absorbance was recorded at $560 \mathrm{~nm}$, and one unit of enzyme activity was taken as that amount of enzyme that reduced the absorbance reading to $50 \%$ in comparison with tubes lacking enzyme. SOD activity was expressed as units per milligram of protein per minute.

Catalase (CAT, EC 1.11.1.6) activity was measured spectrophotometrically according to the method of Chance and Maehly (1955), by monitoring the decline in absorbance at $240 \mathrm{~nm}$ due to $\mathrm{H}_{2} \mathrm{O}_{2}$ consumption. One millilitre of reaction mixture contained $50 \mathrm{mM}$ potassium phosphate buffer $(\mathrm{pH} 7.0)$ and $15 \mathrm{mM} \mathrm{H}_{2} \mathrm{O}_{2}$. The reaction was initiated by adding $50 \mu \mathrm{L}$ of crude extract to this solution. CAT activity was expressed as units ( $\mu \mathrm{mol}$ of $\mathrm{H}_{2} \mathrm{O}_{2}$ consumed per minute) per milligram of protein.

Peroxidase (POD, EC 1.11.1.7) activity was determined by Chance and Maehly (1955) method. One millilitre of reaction mixture contained $13 \mathrm{mM}$ guaiacol, $5 \mathrm{mM} \mathrm{H}_{2} \mathrm{O}_{2}$ and $50 \mathrm{mM}$ potassium phosphate buffer ( $\mathrm{pH} 7)$. Increase in absorbance due to oxidation of guaiacol (extinction coefficient: $26.6 \mathrm{mM} \cdot \mathrm{cm}^{-1}$ ) was monitored at $470 \mathrm{~nm}$ for a minute. Peroxidase activity was expressed as units ( $\mu$ mol guaiacol oxidised per minute) per milligram of protein.

Ascorbate peroxidase (APX, EC 1.11.1.11) activity was measured spectrophotometrically according to Nakano and Asada (1981) by following the decline in absorbance at $290 \mathrm{~nm}$ due to ascorbate oxidation. The oxidation rate of ascorbate was estimated between 1 and $60 \mathrm{~s}$ after starting the reaction with the addition of $\mathrm{H}_{2} \mathrm{O}_{2}$. One millilitre of reaction mixture contained $50 \mathrm{mM}$ potassium phosphate buffer (pH 7), $0.5 \mathrm{mM}$ ascorbate, $0.15 \mathrm{mM} \mathrm{H}_{2} \mathrm{O}_{2}$, $0.1 \mathrm{mM}$ EDTA and $50 \mu \mathrm{L}$ of enzyme extract. APX activity was expressed as units ( $\mu \mathrm{mol}$ of ascorbate oxidised per minute) per milligram of protein.

Protein concentration was determined according to Bradford (1976) by using bovine serum albumin as a standard.

Total phenolic content was determined with Folin-Ciocalteu reagent using gallic acid as a standard phenolic compound. In brief, $1 \mathrm{~g}$ of leaf samples were placed in an Eppendorf tube, with $1 \mathrm{~mL}$ of methanol $(80 \%)$, grinded at $4{ }^{\circ} \mathrm{C}$ and centrifuged $(15000 \times \mathrm{g})$ for $15 \mathrm{~min}$. The extract was mixed with $0.5 \mathrm{~mL}$ of Folin-Ciocalteu reagent (diluted 1:1 with water) and then $1 \mathrm{~mL}$ of a $5 \%$ sodium carbonate solution was also added. After $30 \mathrm{~min}$, absorbance was measured at $725 \mathrm{~nm}$ and expressed as $\mathrm{mg} \cdot \mathrm{g}^{-1} \mathrm{FW}$. 
Proline was extracted and its concentration determined by the method of Bates et al. (1973). Leaf segments were homogenised with $3 \%$ sulfosalicylic acid and the homogenate was centrifuged at $3000 \mathrm{rpm}$ for $20 \mathrm{~min}$. The supernatant was treated with acetic acid and acid ninhydrin, boiled for $1 \mathrm{~h}$ and then absorbance at $520 \mathrm{~nm}$ was determined. Contents of proline are expressed as $\mu \mathrm{mol} \cdot \mathrm{g}^{-1} \mathrm{FW}$.

Glycine betaine was estimated according to the method of Grieve and Grattan (1983). The freezedried plant material was finely ground, mechanically shaken with $20 \mathrm{~mL}$ deionised water for $48 \mathrm{~h}$ at $25{ }^{\circ} \mathrm{C}$. The samples were then filtered and the filtrates were diluted 1:1 with $2 \mathrm{M} \mathrm{H}_{2} \mathrm{SO}_{4}$. Aliquots were kept in centrifuge tubes and cooled in ice water for $1 \mathrm{~h}$. Cold $\mathrm{KI}-\mathrm{I}_{2}$ reagent was added and the reactants were gently stirred with a vortex mixer. The tubes were stored at $4{ }^{\circ} \mathrm{C}$ for $16 \mathrm{~h}$ and then centrifuged at $15000 \times \mathrm{g}$ for $20 \mathrm{~min}$ at $0{ }^{\circ} \mathrm{C}$. The supernatant was carefully aspirated. The periodide crystals were dissolved in 1,2-dichloroethane and then the absorbance was measured at $365 \mathrm{~nm}$ using glycine betaine as standard. Glycine betaine content was expressed as $\mu \mathrm{mol} \cdot \mathrm{g}^{-1} \mathrm{FW}$.

Total yield was determined by adding weight of all produced fruits during 2 months (the experimental period plus four following weeks) and expressed as gram.

\section{Experiment design and statistical analysis}

The experiment was carried out as bi-factorial in a completely randomised design (10 treatments $\times$ 4 times measure). Each treatment category was considered as a level of the first factor, that is 10 levels, and the second factor, that is time of measurement (all parameters were measured weekly for 4 weeks), with four replications with three pots in each replication. Data were analysed by SPSS 16 (ANOVA test) and means were compared using Duncan's multiple range test at $5 \%$ probability level.

\section{RESULTS}

Salt stress caused a significant rise in activity of all antioxidant enzymes. Activity of SOD, CAT, APX, GR and POD increased up to 1.74, 1.37, 2.33, 2.45 and 1.62 folds, respectively, in comparison with non-SNP-treated plants. Application of SNP (50 or $75 \mu \mathrm{M}$ ) under non-saline conditions has also elevating impact on the activity of antioxidant enzymes but lesser than salt. In salt-stressed plants treated with SNP at each application time, activity of antioxidant enzymes was higher compared with control plants and with plants under salinity stress. The highest activity level of CAT and APX was observed in plants treated with $\mathrm{SNP} 50 \rightarrow \mathrm{NaCl}$ and for SOD and POD in plants treated with $\mathrm{SNP} 75 \rightarrow \mathrm{NaCl}$. Activity of GR was significantly higher in plants treated with SNP at both concentrations 1 week before initiation of salt stress in comparison to SNP-treated plants simultaneously or one week after initiation of salt stress (Table 1).

Highest activity level of SOD, APX, GR and POD were obtained in week 4 of experimental period, when salinity and/or exogenous SNP influenced the metabolism (Table 2).

SOD activity increased from 69.20 to 155.32 units $\mathrm{mg}^{-1}$ protein $\cdot \mathrm{min}^{-1}$ (between week 2 and 3 of experimental period) after initiation of salt stress or after sole SNP application (between week 1 and 2). Increase in SOD activity in nonstressed plants, sprayed with SNP was much lower. Maximum of SOD activity, excessing 200 units $\cdot \mathrm{mg}^{-1}$ protein $\min ^{-1}$ was observed in week 4 in plants treated with SNP50 $\rightarrow \mathrm{NaCl}$. This enzyme was also very active in weeks 3 and 4 in the remaining treatments combining $\mathrm{NaCl}$ and SNP (Fig. 1a).

Activity of CAT increased when plants were exposed to saline conditions or when they were treated with SNP under non-saline conditions. Highest activity level of this enzyme was obtained in plants treated with SNP50 $\rightarrow \mathrm{NaCl}$ in weeks 3 and 4 of experimental period, although it was not statistically different when compared with plants treated with SNP (50 or $75 \mu \mathrm{M}$ ), one week after or simultaneously with initiation of stress. Activity of APX (Fig. 1c), GR (Fig. 1d) and POD (Fig. 1e) increased after initiation of salt stress in all treatment categories, especially when salinity was combined with SNP treatment. When SNP was applied alone, activity of APX increased immediately after spraying and decreased within the next 2 weeks (Fig. 1c).

In Table 3, is presented the influence of SNP applied as a single or in combination with $40 \mathrm{mM}$ $\mathrm{NaCl}$ and at different times on the contents of proline, glycine betaine total polyphenols and proteins in the leaves of strawberry 'Selva'. 
Table 1. Effect of 50 or $75 \mu \mathrm{M}$ SNP on activity of some enzymatic antioxidants in 'Selva' strawberry plants grown under $40 \mathrm{mM}$ saline or non-saline conditions

\begin{tabular}{|c|c|c|c|c|c|}
\hline \multirow{2}{*}{ Treatments } & SOD & CAT & APX & GR & POD \\
\hline & $\left(\right.$ units $\cdot \mathrm{mg}^{-1}$ protein $\left.\cdot \mathrm{min}^{-1}\right)$ & \multicolumn{4}{|c|}{ (units $\cdot \mathrm{mg}^{-1}$ protein) } \\
\hline $\mathrm{C}$ & $66.14 \mathrm{~h}^{*}$ & $16.65 \mathrm{f}$ & $9.02 \mathrm{~g}$ & $5.69 \mathrm{~d}$ & $20.79 \mathrm{~g}$ \\
\hline $\mathrm{NaCl}$ & $115.31 \mathrm{e}$ & 22.88 de & $21.04 \mathrm{ef}$ & $13.95 \mathrm{c}$ & 33.73 ef \\
\hline SNP50 & $109.26 \mathrm{f}$ & $25.47 \mathrm{bcd}$ & $23.95 \mathrm{~cd}$ & $13.75 \mathrm{c}$ & $31.24 \mathrm{f}$ \\
\hline SNP75 & $98.85 \mathrm{~g}$ & $20.77 \mathrm{e}$ & $20.03 \mathrm{f}$ & $13.91 \mathrm{c}$ & $37.36 \mathrm{~cd}$ \\
\hline $\mathrm{SNP} 50 \rightarrow \mathrm{NaCl}$ & $133.18 \mathrm{~b}$ & $32.15 \mathrm{a}$ & $32.99 \mathrm{a}$ & $21.74 \mathrm{a}$ & $42.87 \mathrm{~b}$ \\
\hline $\mathrm{SNP} 75 \rightarrow \mathrm{NaCl}$ & $138.01 \mathrm{a}$ & $28.27 \mathrm{~b}$ & $28.44 \mathrm{~b}$ & $22.01 \mathrm{a}$ & $48.00 \mathrm{a}$ \\
\hline SNP50-NaCl & $125.98 \mathrm{c}$ & $26.84 \mathrm{bc}$ & $25.21 \mathrm{c}$ & $17.95 \mathrm{~b}$ & $39.44 \mathrm{c}$ \\
\hline SNP75-NaCl & $125.09 \mathrm{c}$ & $25.48 \mathrm{bcd}$ & $23.54 \mathrm{~cd}$ & $18.53 \mathrm{~b}$ & $43.72 \mathrm{~b}$ \\
\hline $\mathrm{NaCl} \rightarrow \mathrm{SNP} 50$ & $122.42 \mathrm{~cd}$ & $24.68 \mathrm{~cd}$ & $22.34 \mathrm{de}$ & $16.58 \mathrm{bc}$ & $35.14 \mathrm{de}$ \\
\hline $\mathrm{NaCl} \rightarrow \mathrm{SNP} 75$ & $120.92 \mathrm{~d}$ & $23.60 \mathrm{de}$ & $21.46 \mathrm{ef}$ & $16.09 \mathrm{bc}$ & $36.82 \mathrm{~d}$ \\
\hline
\end{tabular}

*Means followed by the same letters within columns are not different at 5\% probability using Duncan's test

Table 2. The activity of some enzymatic antioxidants in 'Selva' strawberry plants under $40 \mathrm{mM}$ saline and in nonsaline conditions, depending on time of measurements

\begin{tabular}{lcccrc}
\hline \multirow{2}{*}{ Treatments } & SOD & CAT & APX & GR & POD \\
\cline { 2 - 6 } & $\left(\right.$ units $\cdot \mathrm{mg}^{-1}$ protein $\left.\cdot \mathrm{min}^{-1}\right)$ & \multicolumn{4}{c}{$\left(\right.$ units $\cdot \mathrm{mg}^{-1}$ protein $)$} \\
\hline Week 1 & $67.71 \mathrm{~d} *$ & $17.11 \mathrm{c}$ & $8.98 \mathrm{~d}$ & $6.04 \mathrm{~d}$ & $22.71 \mathrm{~d}$ \\
Week 2 & $88.21 \mathrm{c}$ & $21.47 \mathrm{~b}$ & $17.78 \mathrm{c}$ & $12.41 \mathrm{c}$ & $30.03 \mathrm{c}$ \\
Week 3 & $143.30 \mathrm{~b}$ & $29.96 \mathrm{a}$ & $30.92 \mathrm{~b}$ & $20.59 \mathrm{~b}$ & $46.32 \mathrm{~b}$ \\
Week 4 & $162.84 \mathrm{a}$ & $30.17 \mathrm{a}$ & $33.51 \mathrm{a}$ & $25.42 \mathrm{a}$ & $49.03 \mathrm{a}$ \\
\hline
\end{tabular}

*Means followed by the same letters within columns are not different at $5 \%$ probability using Duncan's test

Table 3. Effect of 50 or $75 \mu \mathrm{M}$ SNP on contents of proline, glycine betaine, polyphenols and proteins in strawberry 'Selva' plants grown under $40 \mathrm{mM}$ saline or non-saline conditions

\begin{tabular}{lcccc}
\hline Treatments & $\begin{array}{c}\text { Proline } \\
\left(\mu \mathrm{mol} \cdot \mathrm{g}^{-1} \mathrm{FW}\right)\end{array}$ & $\begin{array}{c}\text { Glycine betaine } \\
\left(\mu \mathrm{mol} \cdot \mathrm{g}^{-1} \mathrm{FW}\right)\end{array}$ & $\begin{array}{c}\text { Total polyphenols } \\
\left(\mathrm{mg} \cdot \mathrm{g}^{-1} \mathrm{FW}\right)\end{array}$ & $\begin{array}{c}\text { Total protein } \\
\left(\mathrm{mg} \cdot \mathrm{g}^{-1} \mathrm{FW}\right)\end{array}$ \\
\hline $\mathrm{C}$ & $14.29 \mathrm{f} *$ & $0.32 \mathrm{e}$ & $13.03 \mathrm{~d}$ & $20.15 \mathrm{~b}$ \\
$\mathrm{NaCl}$ & $25.39 \mathrm{c}$ & $0.47 \mathrm{~cd}$ & $16.76 \mathrm{c}$ & $18.06 \mathrm{~d}$ \\
$\mathrm{SNP} 50$ & $22.97 \mathrm{~d}$ & $0.45 \mathrm{de}$ & $18.94 \mathrm{bc}$ & $20.00 \mathrm{bc}$ \\
$\mathrm{SNP75}$ & $20.10 \mathrm{e}$ & $0.44 \mathrm{de}$ & $19.63 \mathrm{ab}$ & $20.00 \mathrm{bc}$ \\
$\mathrm{SNP} 50 \rightarrow \mathrm{NaCl}$ & $34.57 \mathrm{a}$ & $0.65 \mathrm{a}$ & $21.36 \mathrm{a}$ & $21.32 \mathrm{a}$ \\
$\mathrm{SNP} 75 \rightarrow \mathrm{NaCl}$ & $30.69 \mathrm{~b}$ & $0.63 \mathrm{ab}$ & $20.41 \mathrm{ab}$ & $20.30 \mathrm{~b}$ \\
$\mathrm{SNP} 50-\mathrm{NaCl}$ & $30.52 \mathrm{~b}$ & $0.57 \mathrm{abc}$ & $18.32 \mathrm{bc}$ & $20.03 \mathrm{bc}$ \\
$\mathrm{SNP75-NaCl}$ & $29.46 \mathrm{~b}$ & $0.55 \mathrm{abcd}$ & $18.55 \mathrm{bc}$ & $20.09 \mathrm{bc}$ \\
$\mathrm{NaCl} \rightarrow \mathrm{SNP} 50$ & $27.17 \mathrm{c}$ & $0.54 \mathrm{abcd}$ & $17.21 \mathrm{c}$ & $19.54 \mathrm{bcd}$ \\
$\mathrm{NaCl} \rightarrow \mathrm{SNP75}$ & $26.63 \mathrm{c}$ & $0.52 \mathrm{bcd}$ & $16.79 \mathrm{c}$ & $19.19 \mathrm{~cd}$ \\
\hline
\end{tabular}

*Means followed by the same letters within columns are not different at 5\% probability using Duncan's test 


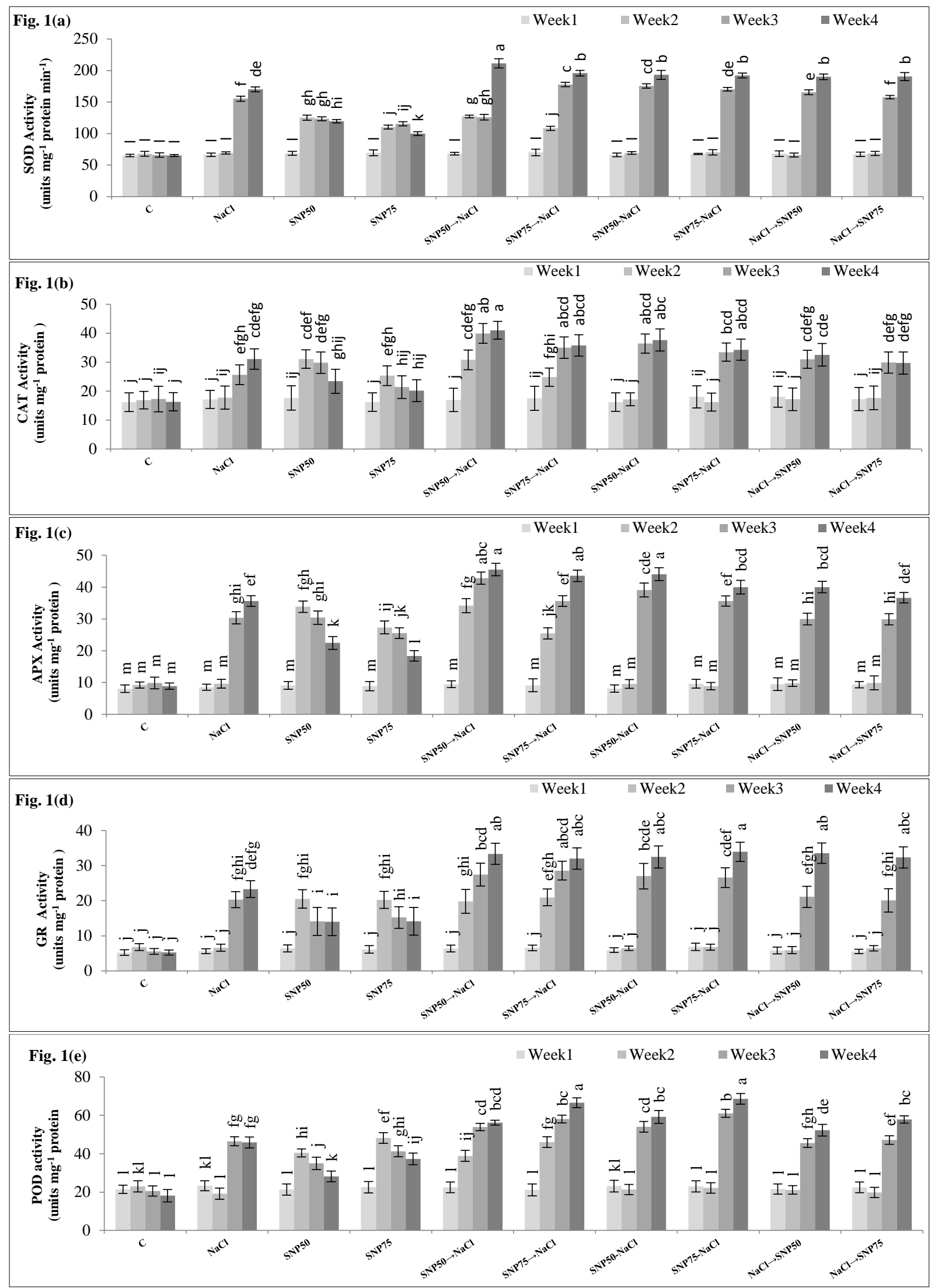

Fig. 1. Changes of enzymatic antioxidants activity: SOD (a), CAT (b), APX (c), GR (d) and POD (e) during experimental period. Columns with the same letters represent means not differing at 5\% probability using Duncan's multiple range test. Vertical bars indicate standard error $(n=4)$ 


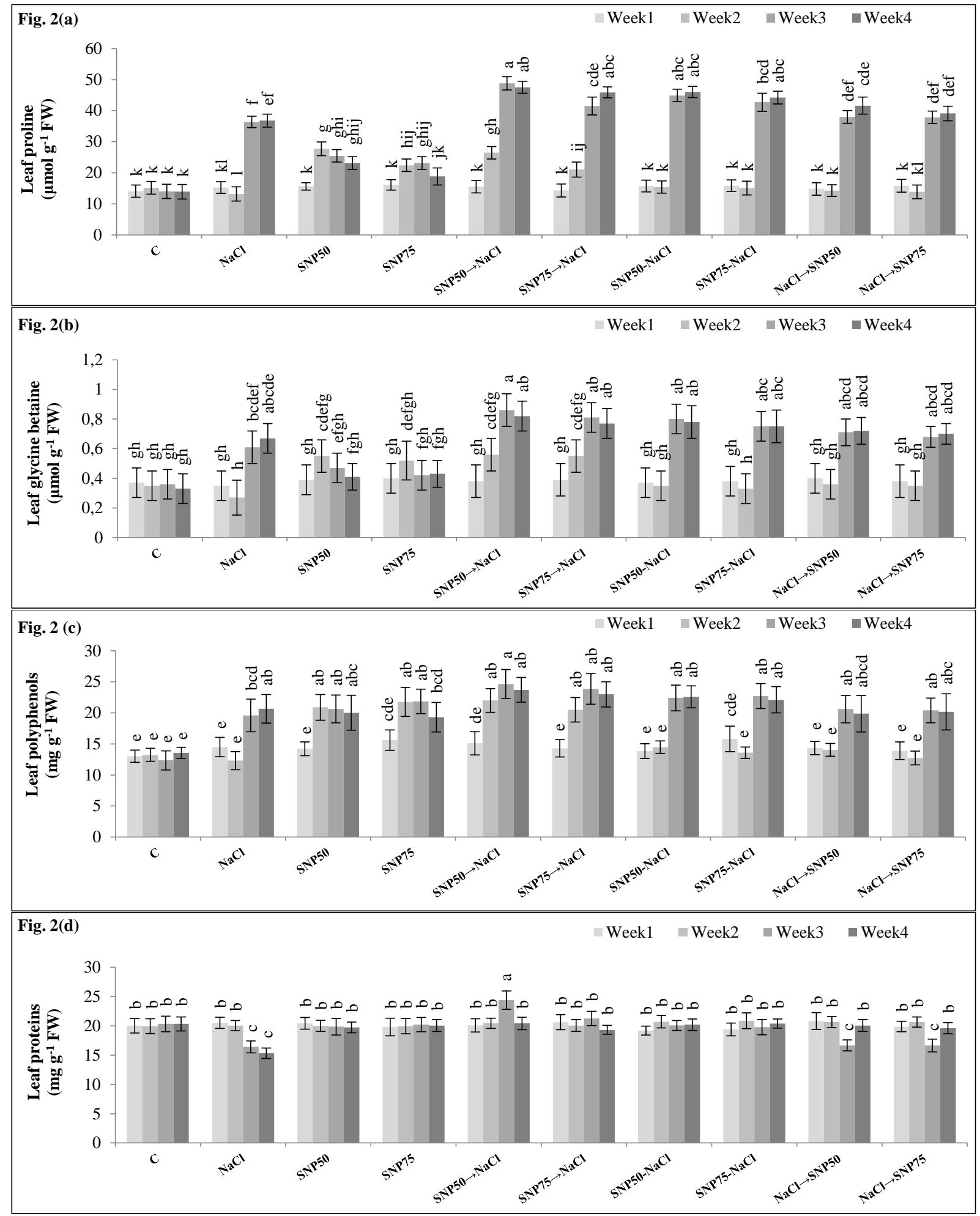

Fig. 2. Changes of leaf proline (a), glycine betaine (b), polyphenols (c) and proteins (d) during experimental period. Columns with the same letters represent means not differing at 5\% probability using Duncan's multiple range test. Vertical bars indicate standard error $(n=4)$ 
Table 4. The contents of proline, glycine betaine polyphenols and proteins in 'Selva' strawberry plants grown under $40 \mathrm{mM}$ saline and in non-saline conditions, depending on time of measurements

\begin{tabular}{lcccc}
\hline Treatments & $\begin{array}{c}\text { Proline } \\
\left(\mu \mathrm{mol} \cdot \mathrm{g}^{-1} \mathrm{FW}\right)\end{array}$ & $\begin{array}{c}\text { Glycine betaine } \\
\left(\mu \mathrm{mol} \cdot \mathrm{g}^{-1} \mathrm{FW}\right)\end{array}$ & $\begin{array}{c}\text { Total polyphenols } \\
\left(\mathrm{mg} \cdot \mathrm{g}^{-1} \mathrm{FW}\right)\end{array}$ & $\begin{array}{c}\text { Total protein } \\
\left(\mathrm{mg} \cdot \mathrm{g}^{-1} \mathrm{FW}\right)\end{array}$ \\
\hline Week 1 & $15.31 \mathrm{c}^{*}$ & $0.38 \mathrm{~b}$ & $14.46 \mathrm{c}$ & $20.07 \mathrm{a}$ \\
Week 2 & $18.44 \mathrm{~b}$ & $0.41 \mathrm{~b}$ & $16.53 \mathrm{~b}$ & $20.32 \mathrm{a}$ \\
Week 3 & $35.27 \mathrm{a}$ & $0.64 \mathrm{a}$ & $20.90 \mathrm{a}$ & $19.55 \mathrm{a}$ \\
Week 4 & $35.69 \mathrm{a}$ & $0.63 \mathrm{a}$ & $20.49 \mathrm{a}$ & $19.53 \mathrm{a}$ \\
\hline
\end{tabular}

*Means followed by the same letters within columns are not different at $5 \%$ probability using Duncan's test.

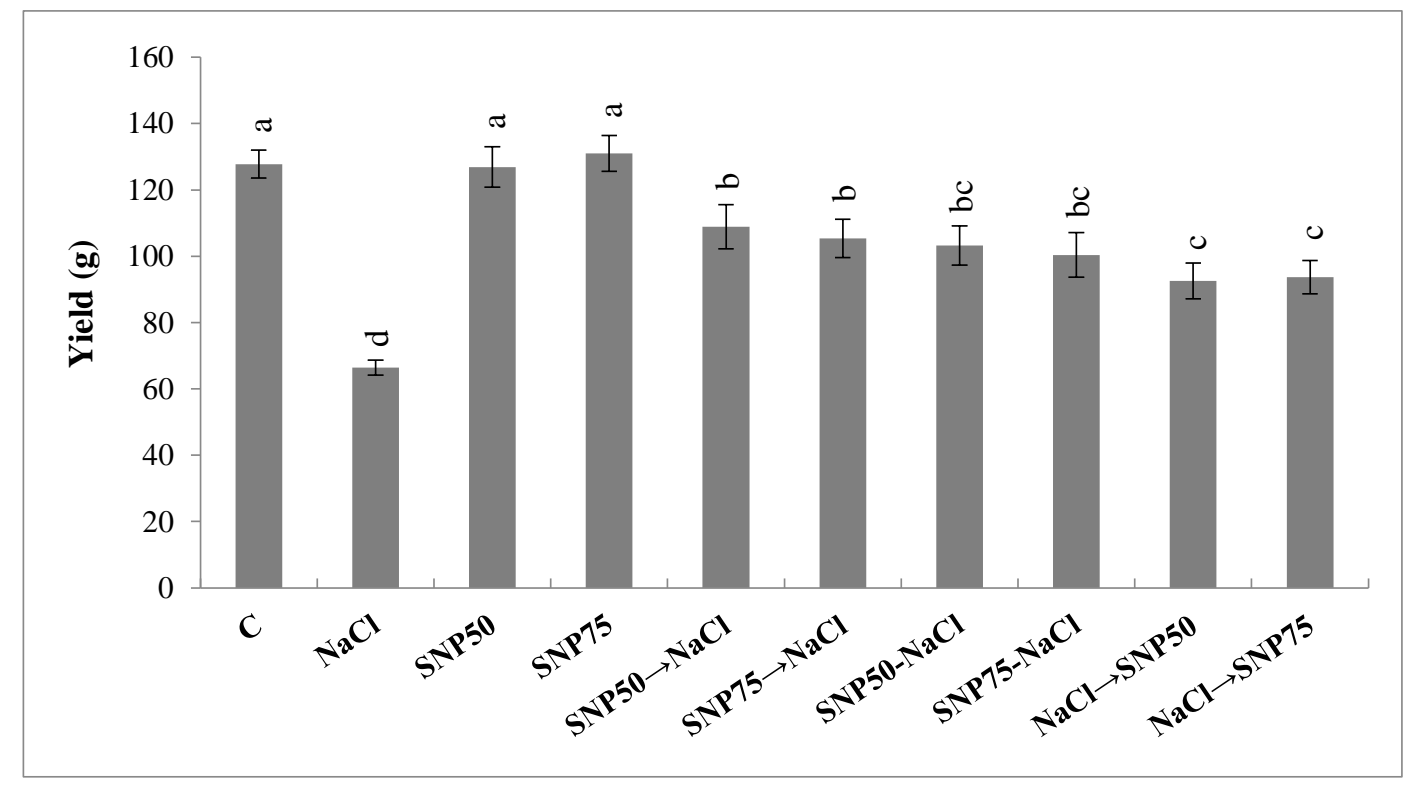

Fig. 3. Total yield of fruits. Columns with the same letters represent means not differing at $5 \%$ probability using Duncan's multiple range test. Vertical bars indicate standard error $(n=4)$

Proline content in the leaves increased by about $77 \%$ in salt-stressed plants, but also in all other treatments in comparison with control. The highest proline content $\left(34.75 \mu \mathrm{M} \cdot \mathrm{g}^{-1} \mathrm{FW}\right)$ was found in plants treated with SNP50 $\rightarrow \mathrm{NaCl}$, and also very high when application of higher concentration of SNP preceded or was given simultaneously with $\mathrm{NaCl}$. When combinations of SNP/NaCl were applied, proline content in the leaves was higher in the weeks 3 and 4 of the experimental period in comparison to those in the weeks 1 or 2 (Table 4, Fig. 2a).

Leaf glycine betaine increased significantly in salt-stressed plants. In plants treated with SNP, the content of this compound was at the level of control. The content of glycine betaine was the highest in the weeks 3 and 4 in salt-stressed and SNP sprayed plants at each application time (Table 3, Fig. 2b).
Total polyphenols concentration in leaves increased by about $29 \%$ in salt-stressed, non-SNPtreated plants, and also in SNP-sprayed plants (Table 3). This parameter was significantly higher in the weeks 3 and 4 in comparison to the weeks 1 or 2 of the experimental period (Table 4) in all treatment categories. The highest level of total polyphenols was found in the treatments, when $\mathrm{NaCl}$ and SNP were applied together (Fig. 2c)

Leaf proteins decreased by $30 \%$ in saltstressed, non-SNP-treated plants, and also in plants treated with SNP after saline stress began. An increase in protein content was recorded only in the week 3, in the treatment where spraying with SNP at $50 \mu \mathrm{M}$ precede $\mathrm{NaCl}$ stress (Table 4, Fig. 2d).

Table 4 indicates how contents of proline, glycine betaine, polyphenols and proteins have 
changed within experimental period. An interactions between treatment category and time of measuremens are presented in Fig. 2 a, b, c, d.

Total yield of plants (Fig. 3) decreased almost twice in the result of salt stress as compared with control. Application of a sole SNP did not influence the fruit yield in comparison with control but in combinations with salt stress SNP ameliorated the harmful effect of $\mathrm{NaCl}$, the more if it was earlier applied (Fig. 3).

\section{DISCUSSION}

Our results confirmed earlier findings of various authors working on different plant species that an activity of SOD, APX, GR, CAT and POD increases under salinity stress (Ahmad et al. 2010; Koyro et al. 2012). Rise in activity of enzymatic antioxidants is a protective reaction of plants in order to prevent damage to cellular components due to overproduction of ROS under saline conditions, and can improve salt tolerance by scavenging of ROS (Alscher et al. 2002). Also, our findings that exogenous $\mathrm{NO}$ causes increase in the activity of the antioxidant enzymes in strawberry 'Selva' plants, are in agreement with other reports. Exogenous application of NO increased activity of CAT, SOD, POD and APX in seashore mallow (Guo et al. 2009), mustard (Zeng et al. 2011), wheat (Ruan et al. 2002), chickpea (Sheokand et al. 2010), and protected plants from oxidative damage under salt stress. Root pre-treatment with NO increased the activity of SOD, CAT, APX and GR, promoted maintenance of cellular redox homeostasis and mitigated oxidative damage under saline conditions in bitter orange (Citrus aurantium L.) (Tanou et al. 2009). Similarly, exogenous NO increased the activity of antioxidant enzymes (SOD, CAT, and APX) in rice, thus increasing its resistance for salinity (Uchida et al. 2002). In tomato, exogenous application of NO increased the activity of antioxidant enzymes SOD, POD, CAT, APX, non-enzymatic antioxidant ascorbate and reduced glutathione under salinity stress thus helping to alleviate salt-induced oxidative damage (Wu et al. 2011).
Leaf polyphenol content was augmented due to the influence of salinity, but the increase was more pronounced in plants treated with SNP one week before the initiation of salinity stress. There are many reports indicating the impact of saline conditions on the increase in content of secondary plant products (Navarro et al. 2006; Neves et al. 2010; Zrig et al. 2011; Petridis et al. 2012). Total phenolics content in strawberry fruits cv. 'Korona', not very sensitive to salinity of soil, increased by $10 \%$ in plants stressed with $40 \mathrm{mM} \mathrm{NaCl}$ (Keutgen \& Pawelzik 2008). At a relatively low salinity, total phenolic content decreased in all analysed mulberry genotypes and increased at higher salinity (Agastian et al. 2000). The study of Rezazadeh et al. (2012) on the effect of salinity on the phenolic content in artichoke gave similar results.

Glycine betaine and proline in our experiment increased significantly in plants exposed to saline conditions; this increase was higher in plants treated with SNP one week before initiation of salt stress. Several osmolytes, including glycine betaine, sugar alcohols, soluble sugars, proline, trehalose, polyols, etc. have been reported to accumulate in various plant species under salinity and drought (Yancey et al. 1982; Bohnert et al. 1995; Hasegawa et al. 2000; Farooq et al. 2009). In addition to their role in the maintenance of water balance in plant tissues, these osmolytes also act as osmoprotectants; for instance, proline scavenges free radicals (Chen \& Murata 2011). NO stimulates cytosolic synthesis of proline and glycine betaine. For example, exogenous application of SNP significantly increased cytosolic proline accumulation in seashore mallow (Kosteletzkya virginica L.), conferring salinity resistance (Guo et al. 2009). Moreover, exogenous NO increased proline accumulation in wheat, where it scavenges ROS and stabilises the structure of the macromolecules (Ruan et al. 2002). Likewise in tomato, same treatment has shown to improve the accumulation of proline as well as soluble sugars under salt stress (Wu et al. 2011).

Total protein content decreased significantly in plants exposed to salinity; this was in accordance with results of previous experiments by Stewart and Bewley (1980), Davies (1987), Feller et al. (2008) and Zhang et al. (2011). 
Importance of application time of SNP (NO) in alleviating salt stress

Strawberry cultivars differ in their salt tolerance (Karlidag et al. 2009) and one of the reason responsible for these differences might be their antioxidant status (Hasanuzzaman et al. 2012). Plants with higher activity of enzymatic and non-enzymatic antioxidants can fight ROS and/or oxidative damage more effectively. A time of exogenous SNP application on strawberry is important because a range of increase in activity of enzymatic antioxidants and content of proline, glycine betaine and polyphenols depends on, whether SNP is applied before, simultaneously or after saline stress initiation. Besides of the antioxidative effect of NO (Beligni et al. 2002), this compound can lead to reduction in $\mathrm{Na} / \mathrm{K}$ ratio in shoots and roots (our study, data not shown) what additionally increases plants tolerance for saline conditions. According to Farooq et al. (2009) NO regulates strategies responsible for salinity resistance. When this signalling molecule reaches a plant before initiation of stress, it triggers reactions which lead to increase in leaves antioxidants activity and higher potential for $\mathrm{K}$ absorption under salinity stress, as a result the plant become more salinity tolerant before $\mathrm{NaCl}$ comes to play. So, when plants are pre-treated with NO, they become pre-conditioned to better tolerance to the salt stress. This could be the reason of the higher yield, shoot and root fresh and dry weigh (data not shown) in plants pre-treated with SNP in comparison to plants treated with SNP after the salt stress initiation. Exogenous application of $\mathrm{NO}$ after initiation of stress can also be helpful, but as some salt-induced damages might convert to irreversible form, plant must expend more energy and resources for damages compensation or recovery. Pre-treatment or at least, NO application at early phases of stress seems a better strategy for protection because plants may avoid the stress effects or tolerate it better.

\section{REFERENCES}

Agastian P., Kingsley S.J., Vivekanandan M. 2000. Effect of salinity on photosynthesis and biochemical characteristics in mulberry genotypes. Photosynthetica 38: 287-290. DOI: 10.1023/A:1007266932623.
Ahmad P., Jaleel C.A., Salem M.A., Nabi G., Sharma S. 2010. Roles of Enzymatic and non-enzymatic antioxidants in plants during abiotic stress. Critical Rev. Biotech. 30(3): 161-175. DOI: 10.3109/07388550903524243.

Ahmad P., Sharma S. 2008. Salt stress and phyto-biochemical responses of plants. Plant Soil Environ. 54(3): 89-99.

Alscher R.G., Erturk N., Heath L.S. 2002. Role of superoxide dismutases $\left(\mathrm{SOD}_{\mathrm{s}}\right)$ in controlling oxidative stress in plants. J. Exp. Bot. 53: 1331-1341. DOI: 10.1093/jexbot/53.372.1331.

Bates L.S., Waldren R.P., Teare I.D. 1973. Rapid determination of free proline for water-stress studies. Plant Soil 39: 205-207. DOI: 10.1007/BF00018060.

Beligni M., Fath A., Bethke P.C., Lamattina L., Jones R.L. 2002. Nitric oxide acts as an antioxidant and delays programmed cell death in barley aleurone layers. Plant Physiol. 129: 1642-1650. DOI: 10.1104/pp.002337.

Bohnert H., Nelson D., Jensone R. 1995. Adaptations to environmental stresses. Plant Cell. 7: 1099-1111. DOI: 10.1105/tpc.7.7.1099.

Bradford M. 1976. A rapid and sensitive method for the quantitation of microgram quantities of protein utilizing the principle of protein-dye binding. Analytical Biochem. 72: 248-254. DOI: 10.1016/00032697(76)90527-3.

Chance B., Maehly A.C. 1955. Assay of catalase and peroxidase. Methods Enzym. 2:764-775. DOI: 10.1016/S0076-6879(55)02300-8.

Chen T.H.H., Murata N. 2011. Glycinebetaine protects plants against abiotic stress: mechanisms and biotechnological applications. Plant Cell Environ. 34: 1-20. DOI: $10.1111 /$ j.1365-3040.2010.02232.x.

Davies K.J.A. 1987. Protein damage and degradation by oxygen radicals. 1. General aspects. J. Biol. Chem. 262: 9895-9901.

Dhindsa R.S., Dhindsa P.P., Thorpe T.A. 1980. Leaf senescence correlated with increased levels of membrane permeability and lipid-peroxidation and decreased levels of superoxide dismutase and catalase. J. Exp. Bot. 32: 93-101. DOI: 10.1093/jxb/32.1.93.

Elstner E.F. 1987. Metabolism of activated oxygen species. In: D.D. Davies (Ed.), The biochemistry of plants, biochemistry of metabolism, San Diego, Academic Press, pp. 252-315. DOI: 10.1016/B9780-12-675411-7.50014-8.

Fan H., Guo S., Jiao Y., Zhang R., Li J. 2007. Effects of exogenous nitric oxide on growth, active oxygen 
species metabolism, and photosynthetic characteristics in cucumber seedlings under $\mathrm{NaCl}$ stress. Frontiers. Agric. China 1: 308-314. DOI: 10.1007/s11703-007-0052-5.

Farooq M., Wahid A., Kobayashi N., Fujita D., Basra S.M.A. 2009. Plant drought stress: effects, mechanisms and management. Agron. Sustainable Develop. 29: 185-212. DOI: 10.1051/agro:2008021.

Feller U., Anders I., Demirevska K. 2008. Degradation of rubisco and other chloroplast proteins under abiotic stress. General App. Plant Physiol. 34(1-2): 5-18.

Foyer C., Halliwell B. 1976. The presence of glutathione and glutathione reductase in chloroplasts: a proposed role in ascorbic acid metabolism. Planta. 133: 21-25. DOI: 10.1007/BF00386001.

Grieve C.M., Grattan S.R. 1983. Rapid assay for determination of water soluble quaternary ammonium compounds. Plant Soil. 70: 303-307. DOI: 10.1007/BF02374789.

Guo Y., Tian Z., Yan D., Zhang J., Qin P. 2009. Effects of nitric oxide on salt stress tolerance in Kosteletzkya virginica. Life Sci. J. 6: 67-75.

Halliwell B., Gutteridge J.M.C. 1985. Free radicals in biology and medicine. Oxford, Clarendon, $888 \mathrm{p}$.

Hasanuzzaman M., Hossain M.A., da-Silva J.A.T., Fujita M. 2012. Plant responses and tolerance to abiotic oxidative stress: antioxidant defenses is a key factors. In: Bandi V., Shanker A.K., Shanker C., Mandapaka M. (Eds.), Crop stress and its management: perspectives and strategies. Springer, Berlin, pp. 261-316. DOI: 10.1007/978-94-007-2220-0_8.

Hasanuzzaman M., Hossain M.A., Fujita M. 2010. Physiological and biochemical mechanisms of nitric oxide induced abiotic stress tolerance in plants. Am. J. Plant Physiol. 5: 295-324. DOI: 10.3923/ajpp.2010.295.324.

Hasegawa P.M., Bressan R.A., Zhu J.K., Bohnert H.J. 2000. Plant cellular and molecular responses to high salinity. Ann. Rev. Plant Physiol. Plant Mol. Biol. 51: 463499. DOI: 10.1146/annurev.arplant.51.1.463.

Karlidag H., Yildirim E., Turan M. 2009. Salicylic acid ameliorates the adverse effect of salt stress on strawberry. Sci. Agric. 66(2): 180-187. DOI: 10.1590/S0103-90162009000200006.

Kepenek K., Koyuncu F. 2002. Studies on the salt tolerance of some strawberry cultivars under glasshouse. Acta Hort. 57: 297-305.

Keutgen A.J., Keutgen N. 2003. Influence of NaCl salinity stress on fruit quality in strawberry. Acta Hort. 609: 155-157.
Keutgen A.J., Pawelzik E. 2008. Quality and nutritional value of strawberry fruit under long term salt stress. Food Chem. 107: 1413-1420. DOI: 10.1016/j.foodchem.2007.09.071.

Kopyra M., Gwozdz E.A. 2003. Nitric oxide stimulates seed germination and counteracts the inhibitory effect of heavy metals and salinity on root growth of Lupinus luteus. Plant Physiol. Biochem. 41: 10111017. DOI: 10.1016/j.plaphy.2003.09.003.

Koyro H.W., Ahmad P., Geissler N. 2012 Abiotic stress responses in plants: an overview. In: P. Ahmad, M.N.V. Prasad (Eds.), Environmental adaptations and stress tolerance of plants in the era of climate change. Springer Science+Business Media, New York, pp. 128. DOI: 10.1007/978-1-4614-0815-4_1.

Misra A.N., Misra M., Singh R. 2011. Nitric oxide: A ubiquitous signaling molecule with diverse role in plants. Afric. J. Plant Sci. 5: 57-74.

Nakano Y., Asada K. 1981. Hydrogen peroxide is scavenged by ascorbate-specific peroxidase in spinach chloroplasts. Plant Cell Physiol. 22: 867-880.

Navarro J.M., Folres P., Garrido C., Martinez V. 2006. Changes in the contents of antioxidant compounds in pepper fruits at different ripening stages, as affected by salinity. Food Chemistry: 96: 66-73. DOI: 10.1016/j.foodchem.2005.01.057.

Neves G.Y.S., Marchiosi R., Ferrarese M.L.L., SiqueiraSoares C., Ferrarese-Filho O. 2010. Root growth inhibition and lignification induced by salt stress in soybean. J. Agron. Crop Sci. 196: 467-473. DOI: 10.1111/j.1439-037X.2010.00432.x.

Petridis A., Therios I., Samouris G., Tananaki C. 2012. Salinity-induced changes in phenolic compounds in leaves and roots of four olive cultivars (Olea europaea $\mathrm{L}$.) and their relationship to antioxidant activity. Environ. Exp. Bot. 79: 37-43. DOI: 10.1016/j.envexpbot.2012.01.007.

Rezazadeh A., Ghasemneshaz A., Barani M., Telmadarrehei T. 2012. Effect of salinity on phenolic composition and antioxidant activity of artichoke (Cynara scolymus L.) leaves. Res. J. Medic. Plants 6: 245-252. DOI: 10.3923/rjmp.2012.245.252.

Ruan H.H., Shen W., Ye M., Xu L. 2002. Protective effects of nitric oxide on salt-induced damages oxidative damages to wheat (Triticum aestivum) leaves. Chinese Sci. Bull. 47: 677-681. DOI: 10.1360/02tb9154.

Saied A.S., Keutgen A.J., Noga G. 2005. The influence of $\mathrm{NaCl}$ salinity on growth, yield and fruit quality of strawberry cultivars 'Elsanta' and 'Korona'. 
Sci. Hortic. 103: 289-303. DOI: 10.1016/j.scienta.2004.06.015.

Sheokand S., Bhankar V., Sawhney V. 2010. Ameliorative effect of exogenous nitric oxide on oxidative metabolism in $\mathrm{NaCl}$ treated chickpea plants. Brazil. J. Plant Physiol. 22: 81-90. DOI: 10.1590/s167704202010000200002.

Siddiqui M.H., Al-Whaibi M.H., Basala M.O. 2011. Role of nitric oxide in tolerance of plants to abiotic stress. Protoplasma 248: 447-455. DOI: 10.1007/s00709-010-0206-9.

Song J., Shi G., Xing S., Chen M., Wang B. 2009. Effects of nitric oxide and nitrogen on seedling emergence, ion accumulation, and seedling growth under salinity in the euhalophyte Suaeda salsa. J. Plant Nutr. Soil Sci. 172: 544-549. DOI: 10.1002/jpln.200800062.

Stewart R.C., Bewley J.D. 1980. Lipid peroxidation associated with accelerated ageing of soybean axes. Plant Physiol. 65: 245-248. DOI: 10.1104/pp.65.2.245.

Tanou G., Molassiotis A., Diamantidis G. 2009. Hydrogen peroxide- and nitric oxide-induced systemic antioxidant prime-like activity under $\mathrm{NaCl}$-stress and stress free conditions in citrus plants. J. Plant Physiol. 166: 1904-1913. DOI: 10.1016/j.jplph.2009.06.012.

Uchida A., Jagendorf A. T., Hibino T., Takabe T., Takabe T. 2002. Effects of hydrogen peroxide and nitric oxide on both salt and heat stress tolerance in rice. Plant Sci. 163: 515-523. DOI: 10.1016/S01689452(02)00159-0.

Wassmann R., Jagadish S.V.K., Heuer S., Ismail A., Redona E., Serraj R., et al. 2009. Climate change af- fecting rice production: the physiological and agronomic basis for possible adaptation strategies. Adv. Agron. 101: 59-122. DOI: 10.1016/S00652113(08)00802-x.

Wu X., Zhu W., Zhang H., Ding H., Zhang H.J. 2011. Exogenous nitric oxide protects against salt-induced oxidative stress in the leaves from two genotypes of tomato (Lycopersicom esculentum Mill.). Acta Physiol. Plant. 33: 1199-1209. DOI: 10.1007/s11738-010-0648-x.

Yancey P., Clark M.E., Had S.C., Bowlus R.D., Somero G.N. 1982. Living with water stress: evolution of osmolyte system. Science. 217: 1214-1222. DOI: 10.1126/science.7112124.

Yilmaz H., Kina A. 2008. The influence of $\mathrm{NaCl}$ salinity on some vegetative and chemical changes of strawberries (Fragaria $\times$ ananassa L.). Afric. J. Biotech. 7(18): 3299-3305. DOI:_10.5897/AJB08.574.

Zeng C.L., Liu L., Wang B.R., Wu X.M., Zhou Y. 2011. Physiological effects of exogenous nitric oxide on Brassica juncea seedlings under $\mathrm{NaCl}$ stress. Biol. Plant. 55: 345-348. DOI: 10.1007/s10535-0110051-5.

Zhang J., Zhang Y., Du Y., Chen S., Tang A. 2011. Dynamic metabonomic responses of tobacco (Nicotiana tabacum) plants to salt stress. J. Prot. Res. 10: 1904-1914. DOI: 10.1021/pr101140n.

Zrig A., Tounekti T., Vadel A.M., Mohamed H.B., Valero D., Serrano M., et al. 2011. Possible involvement of polyphenols and polyamines in salt tolerance of almond rootstocks. Plant Physiol. Biochem. 49: 1313-1322. DOI: 10.1016/j.plaphy.2011.08.009. 